\title{
PENGARUH BAGI HASIL, SIZE, FDR, DAN BI 7-DAY REPO RATE TERHADAP PENGHIMPUNAN DANA PIHAK KETIGA BANK UMUM SYARIAH DI INDONESIA PERIODE 2014-2019
}

\author{
Farida Musrifah \\ Universitas Negeri Surabaya \\ musrifahfarida@gmail.com \\ Mariana \\ Universitas Negeri Surabaya \\ mariana@unesa.ac.id
}

\begin{abstract}
The purpose of this research is to determine the effects from profit sharing, bank size, FDR, and BI 7-Day Repo Rate on the collection of thirdparty funds at islamic commercial banks in Indonesia period 2014-2019. The method of analysis used in this research is Multiple Linear Regression model. The sample of this research was 12 islamic commercial Bank in Indonesia period 2014-2019. The result showed that simultaneously these four variables, namely: profit sharing, bank size, FDR, and BI 7-Day Repo Rate had effect on the collection of thirdparty funds at Islamic commercial banks in Indonesia in 2014-2019. While partially the profit sharing has a positive and significant effect on third party funds, the bank size has a positive and significant effect on third party funds, the FDR has a negative and significant effect on third party funds, and BI 7-Day Repo Rate doesn't effect on third party funds.
\end{abstract}

Keywords: BI Rate; FDR, Profit Sharing, SIZE, Third Party Fund

\begin{abstract}
ABSTRAK
Tujuan dari penelitian ini adalah untuk mengetahui pengaruh bagi hasil, ukuran bank, FDR, dan suku bunga terhadap penghimpunan Dana Pihak Ketiga Bank Umum Syariah di Indonesia periode 2014-2019. Metode analisis yang digunakan dalam penelitian adalah model regresi linear berganda. Hasil penelitian menunjukkan bahwa secara silmutan bagi hasil, ukuran bank, FDR, dan tingkat suku bunga berpengaruh terhadap penghimpunan Dana Pihak Ketiga (DPK) Bank Umum Syariah di Indonesia periode 2014-2019. Sedangkan secara parsial bagi hasil berpengaruh positif dan signifikan terhadap dana pihak ketiga, ukuran bank berpengaruh positif dan signifikan terhadap dana pihak ketiga, FDR berpengaruh negatif dan signifikan terhadap dana pihak ketiga, dan BI 7-Day Repo Rate tidak berpengaruh terhadap dana pihak ketiga.
\end{abstract}

Kata kunci: Suku Bunga, FDR, Bagi Hasil, Ukuran Bank, Dana Pihak Ketiga 


\section{PENDAHULUAN}

Berdasarkan UU RI No. 21 Tahun (2008) tentang perbankan syariah, Bank Syariah adalah bank yang menjalankan kegiatan usaha berdasarkan prinsip syariah atau hukum islam yang diatur dalam fatwa (Majelis Ulama Indonesia, 2020) seperti prinsip keadilan dan keseimbangan, kemaslahatan, universalisme, serta tidak mengandung unsur gharar, maysir, riba, zalim, dan objek yang haram. Sebagai salah satu lembaga intermediary bank syariah melakukan kegiatan operasional yang sama dengan bank konvesional, sebagaimana dijelaskan didalam pasal 4 ayat (1) yaitu bank syariah dan UUS diwajibkan menjalankan kegiatan menghimpun dana dan menyalurkan dana kepada masyarakat. Namun, bank syariah dan bank konvensional juga memiliki sejumlah perbedaan mendasar. Salah satu perbedaan itu terletak pada penentuan return kepada nasabah sebagai depositornya. Dalam menjalankan kegiatannya bank syariah tidak hanya bersifat profit-oriented, tetapi juga mengemban misi-misi sosial. Perkembangan bank syariah di Indonesia diawali dengan berdirinya Bank Muamalat Indonesia pada tahun 1992. Seiring berkembangnya zaman dan adanya kebijakan baru menyebabkan industri perbankan syariah semakin berkembang pesat. Secara kelembagaan, hingga Maret 2020 jumlah bank syariah di Indonesia tercatat sebanyak 14 Bank Umum Syariah, 20 Bank Unit Syariah, dan 163 Bank Pembiayaan Rakyat Syariah dengan jaringan kantor sebanyak 2.929 cabang (www.ojk.go.id, 2020). Sejalan dengan bertambahnya volume industri perbankan syariah, juga didukung oleh kinerja perbankan yang tumbuh positif setiap tahunnya. Kondisi kinerja keuangan perbankan syariah pada bulan Desember 2016 sampai dengan Maret 2020 mengalami pertumbuhan positif, salah satunya diukur dari penghimpunan Dana Pihak Ketiga. Volume DPK pada tahun 2016 sebesar 285,2 triliun, tahun 2017 sebesar 341,9 triliun, sehingga pertumbuhan DPK ditahun 2017 sebesar 19,89\%. Pada tahun 2018 volume DPK tercatat 380,0 triliun dan tahun 2019 sebesar 425,3 triliun. Pertumbuhan DPK tahun 2018 sebesar 11,14\% dan tahun 2019 sebesar 11,39\%. Pada bulan Maret 2020, total penghimpunan DPK mencapai 423,6 triliun. Komponen DPK tertinggi terjadi pada deposito sebesar $53,30 \%$, sedangkan tabungan sebesar $31,93 \%$, dan sisanya giro sebesar 14,77\%. (Otoritas Jasa Keuangan, 2020). Dalam melaksanakan kegiatan operasionalnya bank syariah membutuhkan sumber pendanaan. Sumber pendananan bank berasal dari 3 sumber yaitu dana pihak pertama yang berasal dari pemilik dan laba bank, dana pihak kedua yang diperoleh melalui pasar uang, dan dana 
pihak ketiga yang bersumber dari simpanan masyarakat. Dari ketiga sumber pendanaan tersebut, dana pihak ketiga yang berkontribusi besar sebagai sumber pendanaan dalam kegiatan operasional perbankan. (Andriyanti \& Wasilah, 2010) dalam penelitiannya mengatakan bahwa keberadaan sumber dana bank posisinya sangat vital dan harus dikelola secara optimal, karena akan memberikan ruang gerak bagi perbankan dalam aspek pembiayaan maupun likuiditasnya. Meskipun setiap tahunya volume DPK meningkat, akan tetapi pertumbuhan tersebut hanya berkisar antara $10-20 \%$, bahkan di tahun 2018 pertumbuhan DPK mengalami penurunan hingga $8 \%$. Peningkatan volume DPK mengindikasikan bahwa tingkat kepercayaan nasabah kepada bank semakin tinggi, sedangkan penurunan volume DPK mengindikasikan bahwa tingkat kepercayaan nasabah semakin menurun (Taswan, 2010). Pendapat (Wulandari, 2014) dalam penelitiannya mengatakan bahwa peningkatan dan penurunan DPK dipengaruhi oleh faktor internal dan faktor eksternal. Faktor internal adalah faktor yang berasal dari dalam bank syariah sendiri seperti bagi hasil, SIZE, dan FDR. Sedangkan faktor eksternal berasal dari kondisi ekonomi makro seperti BI Rate. Semakin ketatnya persaingan dalam menghimpun dana masyarakat, maka kegiatan penghimpunan DPK disusun dengan perencanaan yang sangat tertata. Lembaga perbankan berlomba-lomba menawarkan produk simpanan yang memberikan tingkat keuntungan atau bagi hasil yang tinggi. Penelitian Wardati (Mumtazah \& Septiarini, 2016) membuktikan bahwa bagi hasil berpengaruh positif dan signifikan terhadap jumlah DPK yang dihimpun oleh Bank Umum Syariah. Namun, penelitian (Riauwanto \& Sulastiningsih, 2020) bertentangan dengan penelitian wardati, dkk bahwa bagi hasil tidak berpengaruh terhadap penghimpunan DPK. Ukuran bank (SIZE) juga menjadi salah satu faktor pertimbangan bagi nasabah dalam menginvestasikan dananya di bank syariah. Ukuran bank dapat dilihat dari total asset, total penjualan, dan total modal. Hasil penelitian (Riauwanto \& Sulastiningsih, 2020) menyebutkan bahwa total aset berpengaruh positif signifikan terhadap Dana Pihak Ketiga Bank Umum Syariah. Sedangkan hasil penelitian berbeda dilakukan oleh (Abdaliah \& Ikhsan, 2018) menyatakan bahwa ukuran bank tidak berpengaruh terhadap jumlah deposito mudharabah pada perbankan syariah. Faktor internal lain yang mempengaruhi Dana Pihak Ketiga adalah FDR. Financing to Deposit Ratio (FDR) adalah perbandingan antara pembiayaan atau pinjaman yang di berikan oleh bank 
Jurnal Bina Akuntansi, Januari 2022, Vol.9, No.1, Hal. 37 - 55

dengan dana pihak ketiga. Penelitian (Rabsya, 2017) mengatakan bahwa FDR berpengaruh negatif terhadap DPK pada Bank Umum Syariah. Hasil penelitian lain yang dilakukan oleh (Diyanto \& Savitri, 2015) menyatakan bahwa FDR berpengaruh signifikan terhadap deposito mudharabah. Sedangkan hasil penelitian berbeda dilakukan oleh (Juniarty, Mifrahi, \& Tohirin, 2017) menyatakan bahwa variable FDR tidak berpengaruh terhadap deposito mudharabah. Selain faktor internal, Dana Pihak Ketiga juga dipengaruhi oleh faktor eksternal yang berasal dari kondisi makroekonomi seperti Bi 7-Day Repo Rate. Kenaikan BI-Rate akan diikuti oleh kenaikan suku bunga deposito konvensional, hal ini mendorong peningkatan jumlah simpanan deposito pada bank konvensional. Sehingga akan berdampak pada penurunan terhadap jumlah simpanan deposito muḍarabah pada bank syariah. Pendapat ini sesuai dengan penelitian (Jatnika, 2020) bahwa suku

\section{TELAAH LITERATUR}

\section{Dana Pihak Ketiga}

Di dalam UU RI Nomor 10 Tahun (1998) menjelaskan pengertian Dana Pihak Ketiga, DPK atau disebut sebagai simpanan merupakan dana milik masyarakat yang dipercayakan kepada bank syariah sebagai pengelola sesuai dengan akad atau perjanjian tertentu yang tidak bertentangan dengan syariat islam. Bentuk -bentuk simpanan seperti: bunga berpengaruh negatif terhadap dana pihak ketiga BUS di Indonesia. Hasil penelitian (Diyanto \& Savitri, 2015) bertentangan dengan penelitian tersebut bahwa tingkat suku bunga (BI Rate) memiliki pengaruh searah atau positif terhadap Deposito Mudharabah bank. Sedangkan hasil penelitian M. Nur Rianto (Al-Arif \& Hanifah, 2017) bertentangan dengan keduanya bahwa tingkat suku bunga bank umum tidak berpengaruh terhadap volume deposito Bank Umum Syariah di Indonesia. Berdasarkan uraian diatas dapat ditemukan research gap dimana terdapat ketidaksesuaian antara hasil penelitian dengan teori, sehingga perlu dilakukan penelitian lebih lanjut. Tujuan penulis melakukan penelitian adalah untuk menguji konsistensi dari hasil penelitian terdahulu mengenai apakah terdapat pengaruh atau tidak Bagi Hasil, SIZE, FDR, dan BI 7-Day Repo Rate terhadap Penghimpunan DPK Bank Umum Syariah di Indonesia Periode 2014-2019.

a. Giro adalah simpanan dalam bentuk akad wadi'ah sehingga nasabah dapat melakukan penarikan setiap saat.

b. Deposito adalah investasi berdasarkan akad mudharabah dimana masyarakat hanya dapat melakukan penarikan pada waktu tertentu sesuai kesepakatan. 
c. Tabungan adalah simpanan dalam bentuk akad wadi'ah atau berdasarkan

\section{Bagi Hasil}

Pembagian keuntungan didalam sistem bank syariah identik dengan istilah bagi hasil, sedangkan didalam sistem bank konvensional dikenal dengan sistem bunga. Menurut (Sholihin, 2010) bagi hasil adalah pembagian atas hasil usaha antara pemilik modal dan pengelola dana. Secara umum bentuk kerjasama bank syariah terdapat 4 jenis akad, namun pada sistem bagi hasil hanya menggunakan 2 akad yaitu mudharabah dan musyarakah. Di dalam bank syariah sistem bagi hasil dibagi menjadi 2 yaitu Profit Sharing dan Revenue Sharing. Profit Sharing adalah pembagian keuntungan berdasarkan perhitungan total pendapatan setelah dikurangi dengan biaya, sedangkan Revenue Sharing pembagian keuntungan dari total pendapatan sebelum dikurangi biaya. Berdasarkan fatwa mengenai prinsip distribusi bagi hasil usaha LKS No 15 tahun (2000) menyarankan pola bagi hasil sebaiknya menggunakan Net Revenue Sharing yaitu pembagian keuntungan dari pendapatan setelah dikurangi modal.

\section{Ukuran Bank (SIZE)}

Ukuran Bank (bank size) adalah rasio yang digunakan untuk menggolongkan besar kecilnya perusahaan. Ukuran bank dapat dilihat dari jumlah aset, total penjualan, atau kepemilikan modal. Menurut akad mudharabah.

(Pratiwhi, 2008) terdapat 2 alasan mengapa ukuran bank syariah harus ditingkatkan yaitu untuk menjaga stabilitas ekonomi dan menarik sumber pendanaan. Secara teoritis, perusahaan yang tergolong besar salah satunya dilihat dari kepemilikan aset yang besar, akan mampu memberikan keuntungan yang lebih besar dibandingkan dengan perusahaan yang tergolong kecil. Selain itu, semakin baik bank dalam menjalankan kegiatan operasionalnya terutama disebabkan oleh besarnya modal, maka semakin besar tingkat kepercayaan nasabah dalam menempatkan dananya yang akan berimbas pada meningkatnya DPK.

\section{Financing To Deposit Ratio (FDR)}

Financing To Deposit Ratio dalam bank konvensional disebut sebagai Loan Deposit Ratio merupakan rasio yang digunakan untuk mengukur likuiditas suatu bank. Menurut (Kasmir, Bank dan Lembaga Keuangan Lainnya. PT Raja Grafindo Persada, 2008) bank dapat dikatakan likuid apabila bank mampu membayar kembali semua hutang-hutangnya terutama dalam jangka pendek dan mampu memenuhi permintaan pembiayaan nasabah. FDR ditentukan dari rasio keuangan yang diperoleh dari perbandingan antara jumlah pembiayaan yang diberikan dengan dana 
masyarakat yang dihimpun.

\section{BI 7-Day Repo Rate}

Menurut (Diyanto \& Savitri, 2015) BI Rate adalah suku bunga kebijakan yang mencerminkan sikap atau stance kebijakan moneter yang ditetapkan oleh Bank Indonesia dan diumumkan kepada publik. Suku bunga acuhan atau disebut BI Rate sejak 19 Agustus 2016 diganti dengan suku bunga kebijakan baru yaitu BI 7-Day Ripo Rate. Perbedaan BI Rate dengan BI 7-Day Repo Rate adalah terletak pada waktu penarikan dana. BI Rate adalah suku bunga dari SBI, bank umum akan membeli SBI atau istilahnya menyimpan danaya di Bank Indonesia. Setelah satu tahun bank akan mendapatkan bunga tahunan sesuai besaran BI Rate yang telah ditentukan BI. Sedangkan untuk menarik kembali dananya di BI tidak harus menunggu tahunan, sekarang terdapat kebijakan baru penarikan dana dapat dilakukan dalam waktu tujuh hari atau disebut BI 7-Day Repo Rate. BI Rate digunakan sebagai acuhan dalam pengendalian moneter untuk mengarahkan agar rata-rata tertimbang suku bunga SBI- 1 tetap berada di sekitar BI Rate. Suku bunga SBI-1 ini diharapkan dapat mempengaruhi Pasar uang Antar Bank (PUAB). Menurut (Sunardi, 2017) pergerakan suku bunga PUAB akan diikuti pula oleh perkembangan suku bunga deposito dan pada gilirannya bunga kredit perbankan. Sehingga masyarakat akan merespon positif, apaila suku bunga naik, masyarakat akan menyimpan dananya di Bank Konvensional. Hal ini akan berdampak pada penurunan simpanan di bank syariah.

\section{Penelitian Terdahulu dan Penyajian Hipotesis}

Pengaruh Bagi hasil terhadap Dana Pihak Ketiga

Penentuan dan perhitungan bagi hasil bank syariah sangat penting dilakukan diawal perjanjian dengan tujuan untuk menghindari gharar yaitu transaksi yang tidak sesuai dengan prinsip syariah. Para nasabah dalam menempatkan dananya di bank syariah dipengaruhi oleh motif mencari keuntungan. Semakin besar tingkat bagi hasil yang diberikan oleh bank syariah, maka akan semakin tinggi alokasi dana yang diinvestasikan nasabah ke bank. Sehingga akan mempengaruhi besarnya dana pihak ketiga yang berhasil dihimpun oleh bank syariah. Pendapat ini sesuai dengan penelitian (Mumtazah \& Septiarini, 2016) bahwa bagi hasil berpengaruh positif dan signifikan terhadap jumlah DPK.

H1 : Bagi hasil berpengaruh positif signifikan terhadap penghimpunan DPK Bank Umum Syariah di Indonesia periode 2014-2019

Pengaruh SIZE terhadap Dana Pihak Ketiga

Berdasarkan pendapat dari (Abdaliah \& Ikhsan, 2018) pada umumnya deposan menyimpanan dananya di bank dengan 
motif profit maxi matationa (mencari keuntungan). Semakin besar ukuran bank, maka semakin besar pula total aset yang dimiliki oleh bank. Besarnya aset mengindikasikan bahwa kemampuan bank dalam beroperasi semakin baik, sehingga kinerja perbankan dalam penyaluran kredit dan peluang bank untuk mendapatkan profit semakin bertambah. Hal ini akan berdampak pada keinginan nasabah untuk menyimpan dananya di bank tersebut. Sehingga pengimpunan dana pihak ketiga akan meningkat. Pendapat ini sesuai dengan penelitian yang dilakukan oleh (Riauwanto \& Sulastiningsih, 2020) bahwa total aset secara positif dan signifikan berpengaruh terhadap DPK Bank Umum Syariah.

$\mathrm{H} 2$ : Ukuran bank berpengaruh positif dan signifikan terhadap penghimpunan DPK Bank Umum Syariah di Indonesia periode 2014-2019.

Pengaruh FDR terhadap Dana Pihak Ketiga

Financing To Deposit Ratio (FDR) merupakan rasio untuk mengukur tingkat likuiditas yaitu kemampuan bank dalam membayar kembali penarikan dana oleh deposan dengan mengandalkan kredit yang diberikan sebagai sumber likuiditasnya. Semakin besar rasio mengindikasikan bahwa tingkat likuiditas bank semakin rendah, sehingga terdapat kemungkinan bank sedang dalam kondisi bermasalah semakin besar. Hal ini juga akan mempengaruhi tingkat kepercayaan nasabah dalam memilih penempatan dananya dibank. Maka dapat disimpulkan bahwa FDR terdapat hubungan negatif terhadap penghimpunan Dana Pihak Ketiga. Pendapat ini sesuai dengan penelitian (Rabsya, 2017) bahwa Financing To Deposit Rasio (FDR) berpengaruh negatif terhadap DPK Bank Umum Syariah.

H3 : FDR berpengaruh negatif dan signifikan terhadap penghimpunan DPK Bank Umum Syariah di Indonesia periode 2014-2019

\section{Pengaruh BI 7-Day Repo Rate terhadap Dana Pihak Ketiga}

BI Rate merupakan suku bunga yang ditetapkan oleh Bank Indonesia sebagai instrumen kebijakan moneter yang digunakan untuk mempengaruhi jumlah uang yang beredar. Semakin tinggi peningkatkan suku bunga BI Rate akan berdampak pada peningkatkan bunga simpanan dan pinjaman bank konvensional, sehingga masyarakat akan mempertimbangkan sebelum meminjam dana dan cenderung memilih untuk menyimpan dananya di bank konvensional daripada di bank syariah. Hal ini dikarenakan peningkatan bunga simpanan bank konvensional akan meningkatkan pengembalian dana yang akan diperoleh nasabah. Maka dapat disimpulkan bahwa 
suku bunga memiliki hubungan negatif terhadap DPK. Sesuai dengan penelitian (Jatnika, 2020) bahwa suku bunga (BI Rate) memiliki pengaruh negatif terhadap DPK Bank Umum Syariah.

\section{METODOLOGI PENELITIAN}

\section{Desain Penelitian}

Penelitian ini menggunakan metode kuantitatif dan menggunakan data sekunder yaitu data yang diambil dari Laporan Keuangan BUS di Indonesia periode 2014-2019. Data bersumber dari website resmi OJK, sedangkan BI 7-Day Repo Rate diperoleh melalui website resmi Bank Indonesia.

\section{Populasi dan Sampel}

Populasi dalam penelitian ini adalah Bank Umum Syariah (BUS) yang terdaftar di Indonesia periode 2014-2019. Pengambilan sampel menggunakan metode
H4: BI 7-Day Repo Rate berpengaruh negatif dan signifikan terhadap DPK Bank Umum Syariah di Indonesia periode 20142019

purposive sampling, (Sugiyono, 2017) yaitu teknik penentuan sampel penelitian berdasarkan pertimbangan tertentu agar data yang diperoleh bisa lebih representif. Ada beberapa kriteria pengambilan sampel pada penelitian ini yaitu :

1. Bank Umum Syariah yang terdaftar di Indonesia.

2. Bank yang masih aktif beroperasi dan mempublikasikan laporan keuangan selama periode penelitian (20142019).

3. Data laporan keuangan adalah data tahun

Tabel 1. Sampel Penelitian

\begin{tabular}{|c|c|c|}
\hline No & Keterangan & Jumlah \\
\hline 1. & Jumlah keseluruhan BUS periode 2014-2019 & 14 \\
\hline 2. & $\begin{array}{l}\text { BUS yang tidak menyajikan laporan keungan tahun 2014- } \\
2019\end{array}$ & $(2)$ \\
\hline 3. & Jumlah Sample & 12 \\
\hline 4. & Data yang digunakan (12x6 tahun) & 72 \\
\hline \multirow[t]{2}{*}{5.} & Data Outlier & 36 \\
\hline & Jumlah pengamatan & 36 \\
\hline
\end{tabular}

Sumber : Data diolah penulis 
Definisi Operasional dan Variabel

\section{penelitian}

\section{Variable Dependen}

Variable dependen merupakan variabel yang dipengaruhi karena adanya variabel bebas (Ghazali, 2011). Variable dependen (Y) dalam penelitian ini adalah Dana Pihak Ketiga. Pengambilan data DPK diperoleh dari laporan posisi keuangan atau neraca pada sisi liabilitas yang terdapat pada laporan keuangan tahunan bank. Perhitungan DPK diperoleh dari penjumlahan simpanan giro, deposito, dan tabungan.

\section{Variable Independen Bagi Hasil (X1)}

Bagi hasil adalah pembagian atas hasil usaha yang telah dilakukan oleh pihakpihak yang melakukan perjanjian yaitu pihak nasabah dan pihak bank syariah. Menurut pendapat (Muhammad, 2011) jumlah bagi hasil merupakan pembagian laba, dapat berbentuk bonus uang tunai tahunan atau bulanan atas dana investasi yang disimpan pada bank. Perhitungan distribusi bagi hasil sebagai berikut:

Distribusi bagi hasil $=\frac{\text { Total sumber dana bagi hasil }}{\text { Total aktiva produktif }} \times$ Total pendapatan aktiva produktif

\section{Ukuran Bank (X2)}

Ukuran bank adalah ukuran yang

total aset bank pada periode tertentu.

menyatakan besarnya asset yang dimiliki oleh perusahaan. Data ini diperoleh dari laporan keuangan tahunan Bank Umum Syariah periode 2014-2019 yaitu laporan posisi keuangan/neraca pada bagian total aset. Perhitungan rasio ukuran bank diperoleh dari logaritma natural (Ln) dari

\section{FDR (X3)}

FDR merupakan perbandingan antara pembiayaan yang diberikan dengan DPK yang berhasil dihimpun oleh bank. Menurut (Kasmir, 2012) rumus untuk menghitung Financing to Deposit Ratio

$$
\text { FDR }=\frac{\text { Total Financing }}{\text { Total Deposit }} \times 100 \%
$$

\section{BI 7- Day Repo Rate (X4)}

BI 7-Day Repo Rate merupakan suku bunga acuhan menggatikan suku bunga BI Rate. Berdasarkan penjelasan Bank Indonesia, instrumen BI 7-Day Repo Rate digunakan sebagai suku bunga kebijakan baru karena dapat cepat mempengaruhi pasar uang, perbankan, dan sektor rill. Data BI Rate dapat diperoleh dari website resmi
BI.

\section{Teknik Pengumpulan Data}

Teknik pengumpulan data menggunakan studi pustaka yaitu mencari dari berbagai literatur yang ada seperti buku, jurnal ilmiah, skripsi, dan website resmi.

\section{Teknik Analisis Data}

Model yang digunakan dalam analisis data adalah analisis regresi linear berganda. 
Jurnal Bina Akuntansi, Januari 2022, Vol.9, No.1, Hal. 37 - 55

Terdapat beberapa uji dalam analisis data yaitu uji statistik deskriptif, uji asumsi klasik (uji normalitas, uji multikolineritas, uji heteroskedastisitas, dan uji autokorelasi). Tahapan selanjutnya yaitu

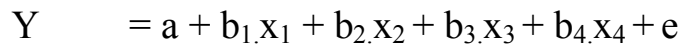

Keterangan :

Y : Dana Pihak Ketiga

a : konstanta

$\mathrm{b}_{1} \quad$ : Koefisien Bagi Hasil

$\mathrm{x}_{1} \quad$ : Bagi Hasil

$\mathrm{b}_{2} \quad$ : Koefisien Ukuran Bank (SIZE)

$\mathrm{x}_{2} \quad$ : Ukuran Bank (SIZE)

\section{HASIL DAN PEMBAHASAN}

Uji Statistik Deskriptif

Tabel 2. Hasil Uji Statistik Deskriptif

\begin{tabular}{lrrrrr}
\hline & N & Minimum & \multicolumn{1}{c}{ Maximum } & \multicolumn{1}{c}{ Mean } & \multicolumn{1}{c}{ Std. Deviation } \\
\hline BGH & 36 & 119.00 & 524.00 & 299.9444 & 105.00774 \\
SIZE & 36 & 28.45 & 30.36 & 29.5247 & .35539 \\
FDR & 36 & 80.52 & 104.75 & 92.1078 & 4.59228 \\
BI RATE & 36 & 4.25 & 7.75 & 5.8750 & 1.36343 \\
DPK & 36 & 1719.00 & 9447.00 & 5375.8611 & 1614.60193 \\
Valid N & 36 & & & & \\
(listwise) & & & & & \\
\hline
\end{tabular}

Sumber: Hasil penelitian (Output SPSS 24, data diolah 2021)

Berdasarkan hasil analisis deskriptif diatas 28.45, dan nilai rata-rata 29.5247. Variabel jumlah sample penelitian berjumlah 36 . FDR memiliki nilai standar deviasi sebesar Variable bagi hasil (X1) memiliki nilai standar deviasi 105.00774, nilai maksimum 524.00, nilai minimum 119.00, dan nilai rata-rata 299.9444. Variable ukuran bank (X2) yang diukur berdasarkan total aset masing-masing BUS memiliki nilai standar deviasi SIZE sebesar 0.35539 , nilai maksimum 30.36, nilai minimum melakukan uji analisis regresi linear berganda meliputi uji koefisien determinasi (R2), uji parsial (uji t), dan uji simultan (uji f). Dibawah ini adalah rumus persamaan regresi linier berganda 
nilai standar deviasi sebesar 1614.60193, nilai maksium 9447.00, nilai minimum 1719.00, dan nilai rata-rata 5375.8611.

\section{Pengujian Asumsi Klasik}

\section{Uji Normalitas}

Salah satu syarat dalam pengujian analisis data adalah uji normalitas, pengujian ini bertujuan untuk mengetahui apakah sebaran data berdistribusi normal atau tidak. Terdapat beberapa cara dalam pengujian normalitas diantaranya uji grafik, chi square, liliefors, shapiro wilk. Namun, pada penelitian kali ini penulis menggunakan uji one sample kolmogorovsmirnov. Hasil pengujian normalitas menunjukkan bahwa nilai Asymp. Sig sebesar 0.20. Berdasarkan pengambilan keputusan tersebut, jika nilai sig lebih besar dari 0.05 , maka data berdistribusi normal. Sehingga dapat disimpulkan bahwa dalam uji normalitas ini telah memenuhi asumsi normalitas.

\section{Uji Multikolinearitas}

Uji Multikolinearitas juga merupakan bagian dari uji asumsi klasik yang digunakan untuk mengetahui apakah didalam model regresi terdapat korelasi antar variable bebas. Pengambilan keputusan pada uji ini dapat dikatakan tidak terjadi multikolinearitas apabila nilai VIF kurang dari 10 dan nilai tolerance lebih besar dari 10. Hasil pengujian menggunakan software SPSS menunjukkan bahwa seluruh variabel bebas (bagi hasil, ukuran bank, FDR, dan BI 7-Day Repo Rate) memiliki nilai VIF < 10 dan nilai tolerance $>0.10$, sehingga dapat disimpulkan bahwa model regresi ini tidak terjadi multikolinearitas.

\section{Uji Heteroskedastisitas}

Tujuan pengujian heteroskedastisitas adalah untuk mengetahui apakah model regresi terjadi ketidaksamaan varian residual suatu pengamatan ke pengamatan lain. Berdasarkan hasil pengujian melalui sofware SPSS menunjukkan bahwa variable bagi hasil, SIZE, dan FDR tidak terjadi heteroskedastisitas dengan nilai sig $>0.05$. Namun terdapat satu variable yaitu BI 7-Day Repo Rate masih terjadi heteroskedastisitas, karena nilai sig $<0.05$. Sehingga untuk memenuhi asumsi maka perlu dilakukan transformasi ke dalam bentuk logaritma. Hasil transformasi menunjukkan bahwa nilai signifikansi untuk semua variabel $>0,05$. Maka dapat disimpulkan bahwa data dalam penelitian ini bebas dari heteroskedastisitas.

\section{Uji Autokorelasi}

Uji autokorelasi digunakan untuk menguji ada atau tidaknya hubungan antara kesalahan penganggu pada periode $\mathrm{t}$ (sesudah) dengan kesalahan pada periode t1 (sebelumnya). Ada beberapa cara yang digunakan dalam pengujian autokorelasi diantaranya mengggunakan uji DurbinWatson dan uji Breusch-Godfrey (uji Langrange-Multiper). Namun, pada 
Jurnal Bina Akuntansi, Januari 2022, Vol.9, No.1, Hal. 37 - 55

penelitian ini penulis mengggunakan cara

Durbin-Watson. Berdasarkan hasil uji

Durbin Watson melalui program SPSS menilai $\mathrm{DW}=1.268$, nilai $\mathrm{n}=36$, dan $\mathrm{k}=4$.

Sehingga didapat angka dengan batas atas (du) sebesar 1.7245, dan batas bawah (dL) sebesar 1.2358. Menurut kriteria pengujian Durbin Watson tidak menghasilkan kesimpulan yang pasti, karena d (Durbin Watson) terletak diantara dl dan du yaitu $\mathrm{dl} \leq \mathrm{d} \leq \mathrm{du}$.

\section{Metode Regresi Linear Berganda}

Tujuan dilakukan pengujian analisis regresi linier berganda menurut (Ghazali, 2011) adalah untuk mengetahui seberapa besar pengaruh variabel independen terhadap variabel dependen. Analisis ini digunakan untuk menentukan diterima atau ditolaknya hipotesis dengan tingkat signifikansi 5\%. Hasil uji analisis regresi dapat dilihat dari tabel 2 dibawah ini.

Tabel 3. Uji-t Coefficient

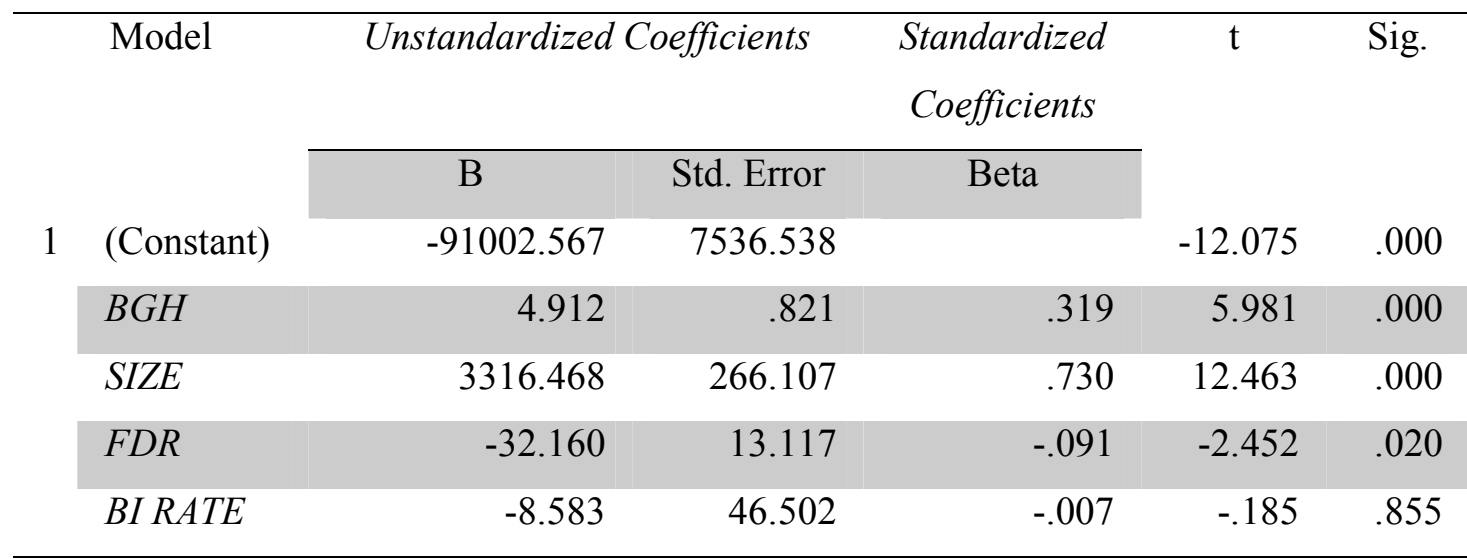

Sumber: Hasil penelitian (Output SPSS 24, data diolah 2021)

Berdasarkan hasil uji coefficients berikut:

persamaan regresi dapat disusun sebagai

$\mathrm{Y}=-91,002.567+4.912$ Bagi Hasil + 3,316.268 Ukuran Bank - 32.160 FDR - 8.583 Bi

Rate

\section{Koefisien Determinasi $\left(\mathbf{R}^{\mathbf{2}}\right)$}

Tujuan dilakukan pengujian koefisien determinasi $\left(\mathrm{R}^{2}\right)$ adalah untuk mengetahui besarnya kontribusi seluruh variabel bebas terhadap variabel terikat, sisanya dipengaruhi variabel bebas lain. Hubungan semakin erat jika koefisien mendekati angka 1, jika menjauhi angka 1 dan mendekati 0 maka hubungan akan semakin lemah. Berdasarkan uji $\left(R^{2}\right)$, nilai $R$ Square sebesar 0.968 artinya variabel bebas yaitu bagi hasil, SIZE, FDR, Bi Rate mampu menjelaskan variansi variabel DPK sebesar $96.8 \%$, dan sisa $3.2 \%$ dipengaruhi oleh variabel lain. 


\section{Uji Parsial (Uji T)}

Uji T digunakan untuk mengetahui apakah masing-masing variable independen memiliki pengaruh terhadap variabel dependen. Berdasarkan pengujian SPSS pada tabel 2 hasil uji $\mathrm{T}$ yaitu:

1. Variabel Bagi Hasil (X1) memiliki $\mathrm{t}_{\text {hitung }}>\mathrm{t}_{\text {tabel }}(5.981>2.039)$ dan sig. $<$ $0.05(0.00<0.05)$ maka $\mathrm{H}_{0}$ ditolak dan $\mathrm{H}_{1} \quad$ diterima. Sehingga dapat disimpulkan bahwa bagi hasil secara parsial berpengaruh positif dan signifikan terhadap Dana Pihak Ketiga.

2. Variabel Ukuran Bank (X2) memiliki $t_{\text {hitung }}>t_{\text {tabel }}(12.463>2.039)$ dan sig. $<0.05(0.00<0,05)$ maka $\mathrm{H}_{0}$ ditolak dan $\mathrm{H}_{1}$ diterima. Sehingga dapat disimpulkan bahwa SIZE secara parsial berpengaruh positif dan signifikan terhadap Dana Pihak Ketiga.

3. Variabel FDR (X3) memiliki $t_{\text {hitung }}<$ $\mathrm{t}_{\text {tabel }}(-2.452<2.039)$ dan sig. $<0.05$
$(0.02<0.05)$ maka $\mathrm{H}_{0}$ ditolak dan $\mathrm{H}_{1}$ diterima. Sehingga dapat disimpulkan bahwa FDR secara parsial memiliki pengaruh negatif dan signifikan terhadap Dana Pihak Ketiga.

4. Variable BI 7-Day Repo Rate (X4) memiliki $t_{\text {hitung }}<\mathrm{t}_{\text {tabel }}(-0.185<2.039)$ dan sig. $>0.05(0.85>0.05)$ maka $\mathrm{H}_{0}$ diterima dan $\mathrm{H}_{1}$ ditolak. Sehingga dapat disimpulkan bahwa BI 7-Day Repo Rate secara parsial tidak memiliki pengaruh terhadap Dana Pihak Ketiga.

\section{Uji Koefisien Regresi Secara Simultan (Uji F)}

Uji $F$ digunakan untuk mengetahui apakah terdapat pengaruh secara silmutan (bersama-sama) beberapa variabel bebas terhadap variable terikat. Cara mengetahui Uji $\mathrm{F}$ dapat dilihat dari nilai signifikansi tabel ANOVA dibawah:

Tabel 4. Hasil Uji-F (ANOVA)

\begin{tabular}{llcc}
\hline & Model & F & Sig \\
\hline 1 & Regression & 237.870 & $.000^{\mathrm{b}}$ \\
& Residual & & \\
& Total & &
\end{tabular}

\author{
a. Dependent Variable: DPK \\ b. Predictors: (Constant), BI RATE, BGH, FDR, SIZE
}

Sumber: Hasil penelitian (Output SPSS 24, data diolah 2021) 
Nilai $F_{\text {hitung }}>F_{\text {tabel }}(237.870>2.67)$ dan nilai sig. $<0.05(0.00<0.05)$ maka Ho ditolak dan $\mathrm{H}_{1}$ diterima. Artinya secara bersama-sama variabel Bagi hasil, SIZE, FDR, dan BI 7-Day Repo Rate berpengaruh terhadap DPK.

\section{Pembahasan}

Pengaruh Bagi Hasil terhadap Penghimpunan Dana Pihak Ketiga.

Hasil pengujian hipotesis menunjukkan bahwa variabel bagi hasil berpengaruh positif dan signifikan terhadap penghimpunan DPK Bank Umum Syariah di Indonesia (2014-2019). Artinya, ketika terjadi peningkatan bagi hasil maka DPK akan meningkat, sedangkan penurunan bagi hasil akan menurunkan jumlah DPK. Perolehan keuntungan atau bagi hasil menjadi pertimbangan utama bagi investor yang akan akan berinvestasi. Sama halnya dengan nasabah yang akan menempatkan dananya dibank, beberapa dari mereka pasti akan mempertimbangkan bagi hasil yang akan diperolehnya. Karena pada dasarnya nasabah dipengaruhi oleh motif mencari keuntungan dalam menempatkan dananya. Jika bank memberikan return yang lebih tinggi, maka banyak nasabah yang tertarik untuk menyimpan uangnya dibank tersebut. Sehingga hal ini akan meningkatkan perolehan Dana Pihak Ketiga. Pendapat ini sama dengan hasil penelitian (Mumtazah \& Septiarini, 2016) yang menyatakan bagi hasil berpengaruh positif dan signifikan terhadap jumlah
DPK Bank Umum Syariah. hasil penelitian wardati, dkk diperkuat oleh penelitian Nila (Juniarty, Mifrahi, \& Tohirin, 2017) yang membuktikan adanya pengaruh searah atau positif bagi hasil terhadap jumlah deposito mudharabah. Penelitian lain dari (Wulandari, 2014) juga mengatakan bahwa jumlah bagi hasil berpengaruh positif dan signifikan terhadap total DPK BUS.

Pengaruh Ukuran Bank (SIZE) terhadap Penghimpunan Dana Pihak Ketiga

Hasil uji hipotesis menunjukkan bahwa variable SIZE berpengaruh positif dan signifikan terhadap penghimpunan DPK Bank Umum Syariah di Indonesia (20142019). Ukuran bank dapat dilihat dari total asset milik perusahaan, jika bank memiliki total asset yang lebih besar maka kemampuan bank dalam beroperasi juga semakin baik. Sehingga terdapat peluang bank untuk meningkatkan pendapatan dan bank mampu memberikan profit yang lebih tinggi kepada nasabah. Umumnya dalam menempatkan dananya, nasabah dipengaruhi oleh motif keuntungan. Oleh karena itu, besarnya asset merupakan salah satunya pertimbangan nasabah dalam menempatkan dananya di bank. Hal ini akan berdampak pada peningkatan jumlah DPK yang dihimpun oleh bank. Pendapat ini sesuai dengan penelitian (Riauwanto \& Sulastiningsih, 2020) bahwa total aset berpengaruh positif signifikan terhadap DPK Bank Umum Syariah. Pendapat 
tersebut juga diperkuat oleh penelitian (Wicaksono, 2018) dan (Setyawati, Arifati, \& Andini, 2016) bahwa ukuran bank berpengaruh positif dan signifikan terhadap jumlah simpanan deposito mudharabah Bank Syariah.

Pengaruh Financing to Deposit Ratio (FDR) terhadap Penghimpunan Dana

\section{Pihak Ketiga}

Hasil uji hipotesis menunjukkan bahwa FDR berpengaruh negatif dan signifikan terhadap penghimpunan DPK Bank Umum Syariah di Indonesia (2014-2019). Tingginya rasio FDR mengindikasikan bahwa tingkat likuiditas bank semakin rendah. Artinya bank dalam kondisi bermasalah semakin besar, bank tidak mampu mengembalikan dana titipan nasabah karena pembiayaan yang disalurkan nasabah lain tidak dapat tertagih atau mengendap, sehingga menyebabkan kredit mancet atau kredit bermasalah. Kondisi ini akan menjadi pertimbangan nasabah dalam menempatkan dananya, sehingga akan berdampak pada jumlah DPK yang diperoleh bank. Hasil ini konsisten dengan penelitian (Rabsya, 2017) bahwa adanya pengaruh negatif FDR terhadap DPK.

\section{Pengaruh BI 7-Day Repo Rate terhadap}

\section{Penghimpunan Dana Pihak Ketiga}

Hasil pengujian hipotesis menunjukkan bahwa tidak ada pengaruh BI 7-Day Repo Rate terhadap penghimpunan DPK Bank
Umum Syariah di Indonesia (2014-2019). Artinya, ketika terjadi peningkatan dan penurunan BI Rate tidak akan mempengaruhi besar kecilnya jumlah DPK yang dihimpun bank. Secara umum, kenaikan BI Rate akan mempengaruhi peningkatan suku bunga bank konvensional. Sehingga nasabah lebih tertarik untuk menyimpan dananya di bank konvensional dari pada di bank syariah yang memberikan suku bunga tinggi. Namun, penelitian ini membuktikan bahwa tinggi rendahnya BI Rate tidak mempengaruhi jumlah DPK. Salah satu faktor yang menyebabkan adalah sebagian nasabah muslim dalam menempatkan dana dibank syariah tidak terpengaruh oleh suku bunga yang tinggi, nasabah tidak sematamata hanya mencari keuntungan, akan tetapi juga didasari oleh tolong menolong atau tabarru'. Selain itu masyarakat muslim menganggap bahwa suku bunga mengandung unsur riba. Adanya fatwa (Majelis Ulama Indonesia, 2020) yang dikeluarkan pada 16 Desember 2003 mempertegas keraguan masyarakat bahwa bunga bank hukumnya haram dan dilarang dalam agama islam. Konsisten dengan penelitian (Abdaliah \& Ikhsan, 2018) bahwa tidak adanya pengaruh suku bunga bank konvensional (BI Rate) terhadap jumlah deposito mudharabah perbankan syariah. Penelitian (Abduh, Omar, \& Duasa, 2011) juga mempertegas BI Rate 
Jurnal Bina Akuntansi, Januari 2022, Vol.9, No.1, Hal. 37 - 55

tidak berpengaruh terhadap jumlah simpanan perbankan syariah di Malaysia.

Pengaruh Bagi Hasil, Ukuran Bank (SIZE), Financing to Deposit Ratio (FDR), dan BI 7-Day Repo Rate terhadap penghimpunan Dana Pihak

\section{Ketiga}

Secara silmutan bagi hasil, SIZE, FDR, dan BI 7-Day Repo Rate berpengaruh terhadap penghimpunan DPK BUS di Indonesia (2014-2019). Penempatan dana oleh nasabah dibank syariah dipengaruhi oleh berbagai faktor yaitu faktor internal dan faktor eksternal. Bagi hasil adalah salah satu faktor internal yang mempengaruhi jumlah DPK. Besarnya bagi hasil yang diberikan bank, akan mempengaruhi jumlah DPK. Nasabah akan memilih menempatkan dananya dibank yang memberikan bagi hasil tinggi, karena pada umumnya nasabah dipengaruhi motif mencari keuntungan dalam menempatkan dananya. Pendapat ini sesuai dengan hasil penelitian Wardati (Mumtazah \& Septiarini, 2016) yang menemukan adanya pengaruh positif bagi hasil terhadap jumlah DPK Bank Umum Syariah. Faktor internal lain yang mempengaruhi jumlah DPK adalah ukuran bank. Salah satu untuk melihat besarnya ukuran bank dapat diketahui dari kepemilikan aset. Semakin besar kepemilikan asset, maka semakin baik kemampuan bank dalam beroperasi. Sehingga nasabah tertarik untuk menempatkan dananya, karena nasabah dapat memperkirakan prospek bank kedepannya. Semakin banyak nasabah menempatkan danaya di bank, semakin besar jumlah DPK yang berhasil dihimpun. Sesuai hasil penelitian (Riauwanto \& Sulastiningsih, 2020) yang menemukan adanya pengaruh positif total aset terhadap jumlah DPK Bank Umum Syariah. Financing to Deposit Ratio (FDR) juga menjadi faktor internal yang mempengaruhi jumlah DPK. Tingginya rasio FDR mengindikasikan bahwa tingkat likuiditas bank semakin rendah. Artinya bank dalam kondisi bermasalah semakin besar, bank tidak mampu mengembalikan dana titipan nasabah karena pembiayaan yang disalurkan nasabah lain tidak dapat tertagih atau mengendap. Hal ini dapat mempengaruhi minat nasabah, sehingga berdampak pada menurunnya jumlah DPK. Pendapat ini ini konsisten dengan penelitian (Rabsya, 2017) yang membuktikan bahwa FDR berpengaruh negatif terhadap DPK. Faktor eksternal yang mempengaruhi DPK salah satunya yaitu BI 7-Day Repo Rate. Namun hasil penelitian menyatakan bahwa peningkatan atau penurunan $\mathrm{Bi}$ Rate tidak mempengaruhi jumlah DPK. Hal ini diseabkan karena penempatan dana oleh nasabah dibank syariah tidak hanya semata- mata untuk mencari keuntungan, namun juga didasari oleh tolong menolong atau tabarru'. Selain itu adanya anggapan masyarakat bahwa suku bunga 
mengandung unsur riba. Pendapat ini sesuai dengan penelitian (Abdaliah \& Ikhsan, 2018) yang menemukan bahwa

\section{SIMPULAN}

Hasil analisis dan pembahasan dapat ditarik kesimpulan bahwa secara parsial terdapat 2 variabel yaitu bagi hasil dan SIZE yang berpengaruh positif terhadap penghimpunan DPK BUS di Indonesia (2014-2019). Sedangkan variabel FDR berpengaruh negatif terhadap penghimpunan DPK BUS di Indonesia (2014-2019). Namun, untuk variabel BI 7 Day Repo Rate tidak berpengaruh terhadap penghimpunan DPK BUS di Indonesia (2014-2019). Secara silmultan semua

\section{DAFTAR PUSTAKA}

Abdaliah, \& Ikhsan, A. E. (2018). Pengaruh Tingkat Bagi Hasil, Tingkat Suku Bunga, Jumlah Kantor, dan Ukuran Bank terhadap Jumlah Deposito Mudharabah pada Perbankan Syariah. Jurnal Ilmiah Mahasiswa Ekonomi Akuntansi,Vol. 3, No. 4 , 538-551.

Abduh, M., Omar, M. A., \& Duasa, J. (2011). The impact of crisis and macroeconomic variables towards Islamic banking deposits. American Journal of Applied Sciences,Vol. 8, No. 12 , 1378-1383. suku bunga atau Bi Rate tidak berpengaruh terhadap jumlah deposito mudharabah perbankan syariah.

variabel yaitu bagi hasil, SIZE, FDR, dan BI 7-Day Repo Rate berpengaruh terhadap penghimpunan DPK BUS di Indonesia (2014-2019). Saran bagi bank syariah diharapkan dapat mempertimbangkan keempat variable tersebut untuk meningkatkan jumlah Dana Pihak Ketiga. Sedangkan untuk penelitian selanjutnya diharapkan dapat menambah populasi dan sample seperti USS (Unit Usaha Syariah) di Indonesia. Selain itu, diharapkan dapat menambah variabel bebas lainnya yang terkait selain variabel yang telah diteliti dalam penelitian ini.

Al-Arif, M. N., \& Hanifah, H. (2017). Determinan Deposito Pada Bank Umum Syariah: Model Regresi Panel. Jurnal Ekonomi Kuantitatif Terapan, 1-107.

Andriyanti, A., \& Wasilah. (2010). Faktor

- Faktor yang Mempengaruhi Jumlah Penghimpunan Dana Pihak Ketiga (Deposito Mudharabah 1 Bulan) Bank Muamalat Indonesia (BMI). Purwokerto: Universitas Jenderal Soedirman.

Diyanto, V., \& Savitri, E. (2015). FaktorFaktor Yang Mempengaruhi 
Jurnal Bina Akuntansi, Januari 2022, Vol.9, No.1, Hal. 37 - 55

Pertumbuhan Deposito Mudharabah

Bank Syariah. Pekbis Jurnal Vol. 7, No. 3 , 187-199.

Ghazali, I. (2011). Aplikasi Analisis Multivariate Dengan Program SPSS: Semarang: Badan Penerbit: UNDIP. Jatnika, M. D. (2020). Pengaruh Variable Makroekonomi Terhadap Dana Pihak Ketiga Bank Umum Syariah Di Indonesia. Jurnal Muara Ilmu Ekonomi Dan Bisnis. Jurnal Muara Ilmu Ekonomi dan Bisnis Vol. 4 No. 1 , 164-173.

Juniarty, Mifrahi, \& Tohirin. (2017). Faktor- Faktor yang Mempengaruhi Deposito Mudharabah pada Bank Syariah Di Indonesia. Jurnal Ekonomi \& Keuangan Islam, Vol. 3, No. 1 , 1686-1698.

Kasmir. (2012). Analisis Laporan Keuangan. . Jakarta: Salemba Empat. Kasmir. (2008). Bank dan Lembaga Keuangan Lainnya. PT Raja Grafindo Persada. Depok: PT Raja Grafindo Persada.

Majelis Ulama Indonesia. (2020). Fatwa Dewan Syari'ah Nasional No: 15/DSN-MUI/IX/2000 Tentang Prinsip Distribusi Hasil Usaha Dalam Lembaga Keuangan Syari'ah. Jakarta: Majelis Ulama Indonesia.

Muhammad. (2011). Manajemen Bank Syari'ah (Kedua). Sekolah Tinggi Ilmu Manajemen YKPN.

Mumtazah, W., \& Septiarini, D. F. (2016).
Analisis Faktor-Faktor yang Mempengaruhi Jumlah Dana Pihak Ketiga pada Bank Umum Syariah Di Indonesia (Periode Triwulan I 2010Triwulan I 2015). Jurnal Ekonomi Syariah Teori Dan Terapan, Vol. 3, No. $10,800-815$.

Otoritas Jasa Keuangan. (2020, Maret). Snapshot Perbankan Syariah Indonesia Maret 2020. Retrieved from ojk.go.id: https://www.ojk.go.id

Pemerintah Republik Indonesia. (1998). Undang-Undang Nomor 10 Tahun 1998 Tentang Perubahan Atas UU No. 7 Tahun 1992 Tentang Perbankan. Jakarta: Pemerintah Republik Indonesia.

Pemerintah Republik Indonesia. (2008). Undang-Undang Republik Indonesia Nomor 21 Tahun 2008 Tentang Perbankan Syariah. Jakarta: Pemerintah Republik Indonesia.

Pratiwhi, Y. (2008). Faktor-Faktor yang Mempengaruhi Pertumbuhan Proporsi Asset Perbankan Syariah di Indonesia. Depok: Universitas Indonesia.

Rabsya, Z. (2017). Analisis Pengaruh Non Performing Financing (NPF), Return On Asset (ROA), Financing to Deposit Ratio (FDR) Terhadap Dana Pihak Ketiga (DPK) Bank Umum Syari'ah Periode 2010-1015. Universitas Islam Negeri Raden Intan Lampung. Lampung: Universitas Islam Negeri Raden Intan Lampung. 
Pengaruh Bagi Hasil, Size, FDR, dan BI 7-Day Repo Rate Terhadap Penghimpunan Dana Pihak Ketiga Bank Umum Syariah di Indonesia Periode 2014-2019

Riauwanto, S., \& Sulastiningsih, S. (2020).

Pengaruh Total Aset dan Bagi Hasil

Perbankan Terhadap Volume Dana

Pihak Ketiga (DPK) pada Bank Umum

Syariah. Jurnal Riset Manajemen

Sekolah Tinggi Ilmu Ekonomi Widya

Wiwaha Program Magister

Manajemen, Vol. 6, No. 2.

Setyawati, V., Arifati, R., \& Andini, R. (2016). Pengaruh Suku Bunga Acuan, Bagi Hasil, Inflasi, Ukuran Bank, NPF, dan Biaya Promosi Terhadap Simpanan Mudharabah Pada Bank Syariah Di Indonesia Tahun 20102014. Journal of Accounting, Vol. 2, No. 2 .

Sholihin, A. I. (2010). Buku Pintar Ekonomi Syariah. Jakarta: PT. Gramedia Pustaka Utama.

Sugiyono. (2017). Metode Penelitian

Kuantitatif, Kualitatif dan $R \& D$ (edisi

26). Bandung: Alfabeta.

Sunardi, N. (2017). Pengaruh BI Rate,
Inflasi dan Kurs Terhadap Indeks Harga Saham Gabungan (IHSG). Jurnal Sekuritas, Vol. 1, No. 2 .

Tan, A. (2014). The Real Secret of Successful Investor and Developer. Jakarta: Elex Media Komputindo.

Taswan. (2010). Manajemen Perbankan Konsep,Teknik, dan Aplikasi. . Yogyakarta: UPP STIM YKPN.

Wicaksono, A. (2018). Faktor-Faktor Yang Mempengaruhi Jumlah Simpanan Deposito Mudharabah (Studi Empiris Di Bank Syariah Mandiri). Surakarta: Universitas Muhammadiyah Surakarta.

Wulandari, S. (2014). Analisis Faktor Internal dan Eksternal yang Mempengaruhi Total Dana Pihak Ketiga (DPK) Bank Umum Syariah di Indonesia (Studi Pada Bank Umum Syariah Periode 2011-2013). . Malang: Universitas Brawijaya. 